\title{
Condom Use in Brazil: An Overview of the Academic Production on HIVIAIDS Prevention (2007-2011)
}

\author{
Thiago Félix Pinheiro ${ }^{1}$ \\ Medical School from the University of São Paulo, São Paulo, Brazil \\ Gabriela Junqueira Calazans \\ Centre for Reference and Training in HIV/AIDS from the Department of Health \\ of the State of São Paulo, São Paulo, Brazil \\ José Ricardo de Carvalho Mesquita Ayres \\ Department of Preventive Medicine from the University of São Paulo, São Paulo, Brazil
}

\begin{abstract}
Since the beginning of the AIDS epidemic, condoms have been the main preventive strategy of the Brazilian policies. This study presents a reflective essay on the academic production on condom use as a method for HIV/AIDS prevention in Brazil, based on papers published in scientific journals between 2007 and 2011 and indexed in the Virtual Health Library. It outlines an overview of these studies and their results and conclusions. Despite the diversity of the production analyzed, it was found that the studies concentrated on young people, with great attention given to gender issues. From combined analysis on the goals and the theoretical and methodological frameworks of the articles, six areas of production of knowledge on the subject were identified: epidemiological studies; studies on knowledge and behavior; studies on specific contexts; studies on senses and meanings; studies on activities; and review studies. The literature analyzed is presented in a diffuse manner so as it interlocks approaches and directions, which requires an epistemological and methodological maturity of the frameworks used.
\end{abstract}

Keywords: Condom, AIDS prevention, safe sex, sexually transmitted infections.

\section{Uso de Camisinha no Brasil: Um Olhar sobre a Produção Acadêmica Acerca da Prevenção de HIVIAids (2007-2011)}

\section{Resumo}

Desde o início da epidemia de aids, a camisinha tem sido a principal estratégia de prevenção das políticas brasileiras. Este estudo apresenta um ensaio reflexivo sobre a produção acadêmica a respeito do uso da camisinha como método de prevenção de HIV/aids no Brasil, com base em artigos publicados em periódicos científicos entre 2007 e 2011 e indexados na Biblioteca Virtual de Saúde. Delineia-se um panorama dos estudos realizados e dos resultados e conclusões encontrados. A despeito da diversidade da produção analisada, identifica-se concentração de estudos realizados com jovens e grande atenção dada às questões de gênero. A partir de uma análise conjunta dos objetivos e do aporte teórico-metodológico dos artigos, são identificadas seis vertentes de produção de conhecimento sobre o assunto: estudos epidemiológicos; estudos de conhecimentos e comportamentos; estudos de contextos específicos; estudos de significados e sentidos; estudos de atividades; e estudos de revisão. A literatura analisada apresenta-

Mailing Address: Departamento de Medicina Preventiva, Faculdade de Medicina, Universidade de São Paulo, Av. Doutor Arnaldo, 455, $2^{\circ}$ andar, sala 2213, Cerqueira César, São Paulo, SP, Brasil, 01246-903. E-mail: tfpinheiro@usp.br, gajuca@usp.brejrcayres@usp.br

Support: This study received support from the Fundação de Amparo à Pesquisa do Estado de São Paulo (FAPESP). 
-se de forma difusa, de modo a entrelaçar abordagens e direcionamentos, o que demanda um amadurecimento epistemológico e metodológico dos referenciais utilizados.

Palavras-chave: Preservativo/camisinha, prevenção de aids, sexo seguro, infecções sexualmente transmissíveis.

\section{Uso de Preservativo en Brasil: Una Mirada a la Producción Académica sobre la Prevención de VIH/SIDA (2007-2011)}

\section{Resumen}

Desde el comienzo de la epidemia del sida, el preservativo ha sido la principal estrategia de prevención de las políticas brasileñas. Este estudio presenta un ensayo reflexivo sobre la producción académica respecto al uso del preservativo como método de prevención del VIH/sida en Brasil, basado en artículos publicados en revistas científicas entre los años 2007 y 2011 e indexados en la Biblioteca Virtual em Salud. Se traza un panorama de los estudios realizados, de los resultados y conclusiones encontrados. A pesar de la diversidad en la producción analizada, se identifica una concentración de estudios realizados con jóvenes y una gran atención dada a los problemas de género. A partir de un análisis conjunto de los objetivos y del aporte teórico-metodológico de los artículos, se identificaron seis vertientes de producción del conocimiento sobre el tema: estudios epidemiológicos, estudios de conocimientos y comportamientos, estudios de contextos específicos, estudios de significados y sentidos, estudios de actividades y estudios de revisión. La literatura analizada se presenta de forma difusa, de manera que se entrelazan enfoques y orientaciones, lo que requiere una madurez epistemológica y metodológica de las referencias utilizadas.

Palabras clave: Preservativo/condón, prevención del sida, sexo seguro, infecciones de transmisión sexual.

\section{Prevention of HIVIAids and Condom Use}

The AIDS epidemic, due to the incurable character of the disease, was presented as a major challenge for public health. In this scenario, harm reduction and prevention were highlighted as key strategies to face the epidemic. In Brazil, since the beginning of policies on AIDS, condoms have been, and continue to be, the main bet in the field of prevention (Paiva, Venturi, França, $\&$ Lopes, 2003). The promotion of condom use was part of a non suppressive approach of prevention, that characterized most successful national responses to the HIV epidemic, unlike other contexts, where preventive work persisted in the idea of sexual abstinence (Kalichman, 1993).

The original proposal to adopt condom use as a strategy for HIV/AIDS prevention dates from the first decade of the epidemic, in the 1980s, from initiatives by the organized gay movement in the United States. This group refused to adopt the proposals from Public Health, who advo- cated the "sanitary isolation" of the population groups in which, according to epidemiological studies of that time, the chance to meet people with the disease was greater than in the so-called general population, the so-called at-risk groups. In resistance to this concept and to the strategies of abstinence and isolation it was proposed the centrality of the concept of risk behavior, and, on this basis, the incorporation of condoms as a way to prevent HIV/AIDS that would allow the maintenance of sexual practices (Ayres, Calazans, Saletti, \& França, 2006).

In this manner, promotion of condom use has been linked, within the historiography of operative concepts for AIDS prevention, to surpassing the idea of at-risk groups through a behavioral conception of prevention, articulated in terms of at-risk behavior versus safe practices. This process has produced a tendency towards universalization of the preoccupation with AIDS, such that it has become possible to work more openly and with greater legitimacy in relation to information and guidance on sexual practices that are safer or 
less safe, and to publicize and teach about how to use condoms. Marketing logic has become imprinted on prevention, such that condom advertising has been emphasized in association with practices and behavioral patterns that it is also desirable to "sell" (Paiva, 2000).

Subsequently, in an attempt to respond to the perception that people's exposure to HIV and to illnesses due to AIDS did not result purely from a set of individual factors, the perspective of vulnerability was elaborated. In this, it was proposed that not only individual but also collective and contextual factors that lead to greater susceptibility to infection and illness should be analyzed. Inseparably, the degree of availability of resources of all orders for both individual and collective protection would also need to be analyzed (Ayres et al., 2006). According to Paiva (2000), the perspective of vulnerability brought into view the limitations of campaigns for publicizing condom use that were conducted out of context and insufficiently explicitly or specific for each group, with its own values, singular sexual preferences and different language for dealing with sexuality.

Adoption of the concept of vulnerability as a guide for prevention and care policies within the national context was linked to "incorporation of the gender perspective and the guarantee of human rights ... [as] fundamental conditions for reducing vulnerabilities and for preventing sexually transmitted diseases and HIV/AIDS" (Ministério da Saúde [MS], 2009). In Brazil, the idea of sex protected through condom use has been integrated as will be seen later on, with the perspective of human rights. Through condom use, a possibility of connecting preventive work with a positive concept of sexual rights has been identified. This not only ensures protection (against violations and diseases) but also promotes the right to pleasure and to satisfactory and safe sex life (Petchesky, 1999).

With antiretroviral therapy freely and universally available in Brazil since the mid-1990s, and with the consequent increase in the population living with HIV, the question of caring for individuals under such conditions, especially within the sphere of sexual health, has emerged. Within this context, protected sex has become strengthened as a possibility for these people's sex lives to continue, along with protection against (re)infection.

On the other hand, since the end of the 1990s and throughout the 2000s, complaints and comments regarding what is generally known as "condom fatigue" or "prevention fatigue" have often been made, as can be observed in articles in the media worldwide ${ }^{2}$ and within the scope of introductions and explanations of some scientific articles that have been based on this social phenomenon, in order to research AIDS prevention (Adam, Husbands, Murray, \& Maxwell, 2005; Ostrow et al., 2008).

In this regard, it does not seem to be accidental that, in entering the fourth decade of coping with the epidemic, major investments in biomedical forms of HIV prevention are being seen around the world. These methods include use of microbicides, pre-exposure prophylaxis (PrEP), post-exposure prophylaxis (PEP), test and treat, treatment as prevention and vaccines. However, even though such strategies have shown promise, they have been regarded in many programs as tools that should be integrated into the strategy of promoting condom use in HIV/AIDS prevention policies of great reach among the population. It is believed that only in this manner will it be possible to make this fourth decade the last of the AIDS epidemic (Joint United Nations Programme on HIV/AIDS [UNAIDS], 2012; United Nations Organization, 2011).

Taking the perspective of the centrality of condoms in coping with the AIDS epidemic, the current nature of the debate and the diversity of academic production in this regard, we present here a reflective essay on the academic produc-

2 With regard to "condom fatigue" or "prevention fatigue", refer to: (a) "Condom fatigue" may be behind STI rise: University of British Columbia. Retrieved June 10, 2012, from http://www.ctv. ca/CTVNews/Health/20070913/bc_sex_070913/; (b) "Condom Fatigue" Leading to More AIDS. Retrieved June, 10, 2012, from http://www. goldtalk.com/forum/showthread.php?t=23956; (c) Condom Fatigue Or Prevention Fatigue? Retrieved June, 10, 2012, from http://ezinearticles.com/?Condom-Fatigue-Or-Prevention-Fatigue?\&id $=5196308$ 
tion relating to condom use as an HIV/AIDS prevention strategy in Brazil. The analysis was undertaken based on studies published in scientific periodicals over the last five years. We started from the assumption that reflection on and comprehension of these studies, their theoretical reference points and their methodological designs might contribute towards understanding the current challenges within the field of prevention and directing new studies with a commitment towards transforming the context of vulnerability to HIV that is faced in this country.

\section{Methodological Path}

The academic production on the topic of this investigation was gathered through a bibliographic search conducted in March 2012, through the Virtual Health Library (BVS) ${ }^{3}$. This portal brings together the main databases in the field of healthcare (LILACS, MEDLINE, COCHRANE and SciELO), thus forming a wide-ranging and practical option for investigating articles that are available through online access open to the public.

We selected studies that presented the Portuguese-language descriptors camisinha, preservativo, sexo seguro or prevenção de aids in their titles, or the same descriptors in English (condom, safe sex or AIDS prevention), with addition of the term Brazil. Among the studies found, we only kept the articles that were available as complete texts that had been published during the last five years (from 2007 to 2011). Studies conducted in other countries were excluded, as were those that did not cover condom use as a method for preventing HIV/AIDS or sexually transmitted infections (STIs) in a general manner, and those with online addresses that were not active and could not be accessed through the link provided by BVS or through other platforms (such as Google). In the end, a total of 38 articles were selected to comprise the analysis material.

The time cutoff was necessary given the large number of articles found in the first steps of the search. Nevertheless, this represents a li-

\footnotetext{
${ }^{3}$ http://brasil.bvs.br
}

mitation of the present study, given that it only covers the most recent production on this topic.

These articles received an initial analysis with a view to outlining a panorama of the academic production on condom use as an $\mathrm{HIV} /$ AIDS prevention strategy, starting from characteristics such as source and year of publication, participants and region in which the study was conducted. Following this, we conducted a more detailed analysis regarding the objectives, theoretical-methodological basis and results of the studies. The analytical process then consisted of exploratory, selective and analytical readings of the articles.

\section{Panorama of the Literature: Contexts of Knowledge Production and Dissemination}

The articles analyzed (Table 1) were published over the course of the five-year period investigated, with nonlinear distribution, such that we were unable to discern any increase or decrease in the numbers of published papers on condom use as a strategy for prevention of HIV/ AIDS over this period. We found that there were few studies of national coverage and that the great majority had been produced in specific localities in Brazil. There were studies from all regions of the country, but the numbers were smallest in the Central-Western and Northern regions.

According to the classification of the scientific periodicals present in the BVS, the articles analyzed were concentrated in periodicals connected with public health and nursing, which shows that there was some funneling of the discussion on this matter into these fields. Following this, in smaller proportions, we found articles in periodicals relating to medicine and other fields of healthcare, particularly the field of STIs. It was noticeable that there was only a single article published in a psychology periodical.

Most of the articles concentrated on studying male condoms, but some included or exclusively studied female condoms. Here, we did not make any separation according to this criterion, since we were considering condom use in a general manner. In some articles, condom as a 
Table 1

Characterization of the Articles Reviewed

\begin{tabular}{|c|c|c|c|c|c|}
\hline $\begin{array}{l}\text { Year of } \\
\text { publi- } \\
\text { cation }\end{array}$ & $\mathrm{N}^{\circ *}$ & Authors & Study participants** & $\begin{array}{l}\text { Study } \\
\text { location }\end{array}$ & $\begin{array}{l}\text { Field of know- } \\
\text { ledge of the } \\
\text { periodical }{ }^{* * * *}\end{array}$ \\
\hline \multirow[t]{5}{*}{2007} & 1 & Leite et al. & University students $* * *$ & PI & Nursing \\
\hline & 2 & Carvalho, Bezerra, Leitão, Joca and Pinheiro & Young people*** & $\mathrm{CE}$ & Nursing \\
\hline & 3 & Maliska, Souza and Silva & Women with HIV & $\mathrm{SC}$ & Nursing \\
\hline & 4 & $\begin{array}{l}\text { Benzaken, Galbán Garcia, Sardinha, Pedrosa } \\
\text { and Paiva }\end{array}$ & - & $\mathrm{AM}$ & Public health \\
\hline & 5 & Viana, Faúndes, Mello and Sousa & Students $* * *$ & MG & Public health \\
\hline \multirow[t]{11}{*}{2008} & 6 & S. M. Barbosa, Costa and Vieira & Parents of adolescents $* * *$ & $\mathrm{CE}$ & Nursing \\
\hline & 7 & Alves and Lopes & University students $* * *$ & $\mathrm{SP}$ & Nursing \\
\hline & 8 & Marta, Francisco, Martins and Clos & University students $* * *$ & $\mathrm{RJ}$ & Nursing \\
\hline & 9 & Madureira and Trentini (a) & Heterosexual couples & - & Nursing \\
\hline & 10 & Saldanha et al. & Students $* * *$ & PB & STI \\
\hline & 11 & Lima, Silva, Godoi and Merchán-Hamann & Men who have sex with men & $\mathrm{DF}$ & Medicine \\
\hline & 12 & $\begin{array}{l}\text { Berquó, Barbosa, Lima and Grupo de } \\
\text { Estudos em População, Sexualidade e Aids }\end{array}$ & General urban population & Brazil & Public health \\
\hline & 13 & $\begin{array}{l}\text { Paiva, Calazans, Venturi, Dias and Grupo de } \\
\text { Estudos em População, Sexualidade e Aids }\end{array}$ & Adolescents*** & Brazil & Public health \\
\hline & 14 & Oliveira, Moura, Guedes and Almeida & Health professionals (STI/AIDS) & $\mathrm{CE}$ & Public health \\
\hline & 15 & M. C. P. Sousa, Espírito Santo and Motta & Women & PI & Public health \\
\hline & 16 & Madureira and Trentini (b) & Heterosexual men & $\mathrm{SC}$ & Public health \\
\hline \multirow[t]{9}{*}{2009} & 17 & R. K. Reis and Gir & Serodiscordant couples & $\mathrm{SP}$ & Nursing \\
\hline & 18 & Kalckmann, Farias and Carvalheiro & Women & $\mathrm{SP}$ & Epidemiology \\
\hline & 19 & Matos, Veiga and Reis & Students $* * *$ & MG & $\begin{array}{l}\text { Gynecology/ } \\
\text { Obstetrics }\end{array}$ \\
\hline & 20 & Moura, Lima, Farias, Feitoza and Barroso & Women prostitutes & $\mathrm{CE}$ & STI \\
\hline & 21 & Brisighelli, Araújo, Doher and Haddad & - & - & Medicine \\
\hline & 22 & Costa, Rosa and Battisti & University students $* * *$ & $\mathrm{SC}$ & Public health \\
\hline & 23 & Ferraz and Nemes & - & $\mathrm{SP}$ & Public health \\
\hline & 24 & Maksud & Serodiscordant couples & - & Public health \\
\hline & 25 & $\begin{array}{l}\text { A. A. Sousa, Lucareski, Brizolara, Bortoletto } \\
\text { and Pinto }\end{array}$ & - & $\mathrm{SP}$ & Public health \\
\hline \multirow[t]{4}{*}{2010} & 26 & Nicolau and Pinheiro & Female inmates & $\mathrm{CE}$ & Nursing \\
\hline & 27 & Sampaio, Paixão, Andrade and Torres & Adolescents*** & $\mathrm{PE}$ and $\mathrm{BA}$ & Psychology \\
\hline & 28 & Riscado, Oliveira and Brito & $\begin{array}{l}\text { Women in remnant communities } \\
\text { of former slaves }\end{array}$ & $\mathrm{AL}$ & Public health \\
\hline & 29 & Cruzeiro et al. & Adolescents*** & RS & Public health \\
\hline \multirow[t]{9}{*}{2011} & 30 & Maschio, Balbino, Souza and Kalinke & Elderly people*** & PR & Nursing \\
\hline & 31 & Laroque et al. & Elderly people*** & RS & Nursing \\
\hline & 32 & Gomes, Fonseca, Jundi and Severo & Heterosexual couples & RS & Nursing \\
\hline & 33 & Ribeiro, Silva and Saldanha & Young people*** & PB & STI \\
\hline & 34 & Albuquerque and Villela & Women & $\mathrm{CE}$ & Care provision \\
\hline & 35 & Rebello, Gomes and Souza & Men & - & Public health \\
\hline & 36 & Sampaio, Santos, Callou and Souza & Adolescents*** & $\mathrm{PE}$ and $\mathrm{BA}$ & Public health \\
\hline & 37 & C. B. Reis and Bernardes & Inmates $* * *$ & MS & Public health \\
\hline & 38 & Borba & $\begin{array}{l}\text { Transvestites working as } \\
\text { Transvestites prostitutes }\end{array}$ & $\begin{array}{l}\text { Southern } \\
\text { Brazil }\end{array}$ & Public health \\
\hline
\end{tabular}

Note. *Identification number for the article, used to organize our analysis. **According to the descriptions given in the articles. ***Participants of both sexes. $* * *$ According to the BVS classification. 
method for HIV/AIDS prevention was the central theme. In others, this subject appears as part of the broader theme of STI prevention. There were also articles in which this topic was linked to other discussions, such as in relation to sexual initiation, contraception, violence, racism, use of healthcare services, etc.

In the literature analyzed, the terms camisinha, preservative and condom were found and were used in the searches of the bibliographic databases. In the present description, however, we used the term condom uniformly, even when the original text made use of other expressions. In the Portuguese version, we adopted the term camisinha as this term seems to us to be more associated with approaches that place value on the sociocultural aspects of sexual practices and the perspective of prevention guided by the theoretical framework of vulnerability and human rights, as opposed to terms that tend to form part of discourse that takes a more strictly biomedical line regarding infection, centered on preventive strategies for specific protection ${ }^{4}$.

\section{Knowledge Produced: Systematization of the Studies and Presentation of the Results}

The articles presented significant diversity in relation to what they proposed to investigate and their study designs. Thus, they differed regarding the type of knowledge produced. Hence, in order to assess and discuss the studies found, along with their results, it seemed to us to be useful to group them through combined analysis of the objectives and the theoretical-methodological basis. In this manner, we identified six strands of study on condom use as a strategy for HIV/ AIDS prevention (Table 2).

This systematization fulfilled the purpose of discussing what types of knowledge had been produced in the field in question and on what it had been based. However, this did not take into

4 For a comparison between the fundamentals and methods of the main conceptual frameworks of prevention, refer to: Ayres, Paiva and França (2011). account all the elements that characterized the studies, which could have led to other ways of analyzing them.

Starting from these strands, which expressed different forms of logic in constructing knowledge within the field investigated, we move on to presenting the studies and their results.

\section{Epidemiological Studies}

Among the studies on the prevalence of condom use, we can highlight those of national coverage. In this regard, two of the articles analyzed presented data from the survey "Sexual behavior and perceptions of the Brazilian population regarding HIV/AIDS" [Comportamento sexual da população brasileira e percepções do HIV/AIDS], which were gathered in 1998 and 2005, from representative samples of the urban population of this country.

Berquó et al. (2008) presented data on condom use among people aged 16 to 65 years over the 12 months prior to the survey and showed that there had been a substantial increase between 1998 and 2005. This increase was seen among people who only had casual partnerships (from $63.5 \%$ to $78.6 \%$ ), those who only had a steady partnership (from $19.1 \%$ to $33.1 \%$ ) and those with both types (from $24.5 \%$ to $46.3 \%$ ). The prevalence of use in the first group was higher than in the other groups. Overall, in 2005, 21\% of the people said that they had made consistent use of condoms, i.e. in all sexual intercourse over the 12 months investigated. Young people (16 to 24 years of age) were highlighted as the segment that best protects itself.

Paiva et al. (2008) concentrated specifically on the young participants of this survey (segment from 16 to 19 years of age) and particularly investigated condom use in sexual initiation. Towards similar results to the previous study, they found an increase both in the case of the first sexual experience took place in a steady relationship (from $48.5 \%$ to $67.7 \%$ ), as in the case of a casual partnership (from $47.2 \%$ to $62.6 \%$ ). This increase did not occur for some young people in relation to religion (Protestants and no religion), family income and having had their first sexual intercourse before age 14 . 
Table 2

Characterization of the Strands of Research in the Studies on Condom Use as an HIV/AIDS Prevention Strategy

Research Characterization
strand

Research Characterization

Epidemiolo- These studies identified the prevalence of condom use or occurrence related in gical studies certain group or population segment and/or investigated factors associated with use of condoms. These studies had adopted quantitative methodology.

Studies on knowledge and behavior

These studies sought to identify the level of information that a certain group had in relation to STI/AIDS and preventive methods, along with sexual practices and behavior relating to condom use. They were based on behavioral concepts of HIV/AIDS prevention (at-risk behavior versus safe practices). There is variation and combination of quantitative and qualitative methodologies.

Studies on specific contexts

Studies on senses and meanings

Studies on activities

Studies of literature review

\begin{abstract}
These studies were circumscribed to a particular context of research, in seeking to understand the possibilities for and challenges of prevention of HIV/AIDS in specific situations or groups. They prioritized the study of sociocultural aspects and had adopted qualitative methodology.
\end{abstract}

These studies were focused on the senses and meanings attributed by people or groups to condom use or unprotected sex, in seeking to comprehend how symbolic constructs regarding these practices might hinder or facilitate prevention. These studies had adopted qualitative methodology.

These were case studies on activities that promoted condom use as a preventive measure for HIV/AIDS or studies that involved such activities as part of the research, and they analyzed the possibilities and challenges of the situation examined. These studies were justified in terms of publicizing experiences that could be taken as examples or deserved to be debated. They also encompassed participatory research. They had adopted predominantly qualitative methodology.

These studies provided review of scientific literature produced in relation to condom use as a prevention strategy for HIV/AIDS. They were summarized and/or analyzed within a certain theoretical framework or thematic focus. In reviewing the literature, a diversity of styles and ways of working were encompassed.
Articles

identified

according to

category

$5,11,12,13$ $18,22,29,30$, 33

1, 2, 6, 7, 8, $10,14,19,26$, 31

$15,20,28,37$

$3,9,16,17$ $24,27,32,36$

$4,23,25,34$, 38

21,35
The other articles in this strand of research presented studies that had been conducted among certain population groups and in specific localities in the country. Most of these studies aimed to investigate condom use among young people, like the study by Cruzeiro et al. (2010), who presented a household survey with a representative sample of the segment 15-18 years living in the urban zone of Pelotas, RS. In this stu$\mathrm{dy}$, it was investigated the occurrence of "risky sexual behavior", defined in terms of the num- ber of sexual partners in the last 12 months and condom use in the last three sexual intercourses. Regarding the second indicative, the use of condoms was constant for $56.3 \%$ of the participants. For girls, the risk of using condoms only occasionally increases by $21 \%$, compared with boys. The authors observed a linear trend with respect to maternal education, as the occasional use shown greater the lower the years of schooling of the mother.

Costa et al. (2009), Ribeiro et al. (2011) and 
Viana et al. (2007) also investigated condom use among the young population, in this case, however, only with young people within the educational system. The first two of these studies compared condom use between the first and the most recent sexual intercourse.

Costa et al. (2009) identified, among college students with a mean age of 23.6 years, the prevalence of $71.4 \%$ in first and $61.4 \%$ in the last sexual intercourse. Regarding the associated factors, this research shows that having candidiasis is a protective factor for condom use in the first and last sexual intercourse. Moreover, having a non-stable marital relationship and having a partner who was doing a health-related course were positively associated with condom use during the last sexual intercourse. Among the subjects themselves, doing a health-related course was not significantly associated with condom use.

Ribeiro et al. (2011), in turn, observed among public school students (12-20 years) the absence of condoms decreased among males (from $35 \%$ in the first intercourse to $21 \%$ in the last) and increased among females (from 39\% to $43 \%$ ). Referring to all sexual intercourse, the difference according to sex was also significant in this study. The majority of the boys (53\%) said that they always used a condom, while the majority of the girls (54\%) said that they used them sometimes. According to the researchers, this difference might be related to the fact that the majority of the steady relationships (68\%) were reported by women, while a proportion of the men $(38 \%)$ said that they had had four or more sexual relationships. However, no other data relating to the type and quantity of relationships were presented in the article.

Other factors associated with condom use among young people were found by Viana et al. (2007). These researchers found among sexually active students at public schools, aged between 10 and 19 years that being male and having healthcare professionals involved in teaching were positively associated with all the safe sex indicators investigated. Furthermore, having a mother with more than eight years of schooling was positively associated with condom use with either a steady or a casual partner, while being a student at high school level (in comparison with being a student at elementary school level) and being older were associated negatively with consistent condom use with casual and steady partners, respectively.

Condom use among other groups was also investigated in the studies along this research strand. For example, the elderly population was the focus of the study by Maschio et al. (2011), who investigated measures to prevent STI/AIDS by patrons of an institution that develops progra$\mathrm{ms}$ to improve the quality of life in old age. In this study, the majority of the participants (87.7\%) expressed the need to use preventive measures, among which condom use was prominent as the best-known method (mentioned by $70 \%$ of the participants). However, only $42.8 \%$ reported having used a preventive measure, among which $64.2 \%$ made reference to condom use.

The study by Kalckmann et al. (2009) focused specifically on use of female condoms. In monitoring the use of these condoms in public healthcare services (which participated in a project to implement their use), the researchers found that only $14.4 \%$ of the women investigated had made continuous use over a 12-month period. The women with higher frequency of sexual intercourse per month used the female condom for longer times, as did those who used the healthcare services of community projects, in comparison with those who used primary healthcare units and specialized services. Using a contraceptive practice and the method chosen were not shown to be associated with continuity of use.

The study by Lima et al. (2008) focused on men who have sex with men (MSM) and, among other aspects, investigated their use of healthcare services (specialized in STIs), to obtain condoms. In this regard, the researchers found that, among the participants, the younger men were buying condoms with noticeable frequency, although less frequently than the older men. In relation to socioeconomic status, men with lower income have less access to condoms, especially at "gay meeting points". From a table in this study that presented the forms of access to condoms, it can be seen that in a general manner, condoms were being bought or were being acquired at "gay meeting points" and events more 
often than they were being acquired through healthcare services or non-governmental organizations.

\section{Studies on Knowledge and Behavior}

Studies on knowledge and behavior tend to make use of theoretical-methodological models based on behavioral and socio-cognitive studies, such as studies on Knowledge, Attitudes and Practices (Alves \& Lopes, 2008; Marta et al., 2008; Nicolau \& Pinheiro, 2010); Theory of Stages of Change (S. M. Barbosa et al., 2008); Theory of Planned Behavior (Matos et al., 2009); and The Behavioral Risk Factor Surveillance System (Saldanha et al., 2008).

Furthermore, most of the studies along this strand of research focused on investigating condom use among young people. However, each study presented particular features due to the segment investigated and the research design.

The studies by Alves and Lopes (2008) and Marta et al. (2008) put forward analyses that covered knowledge, attitudes and practices among young people. Alves and Lopes (2008) conducted a study among university students aged 18 to 19 years in relation to contraceptive pills and condoms. They found that the participants had high levels of knowledge and positive attitudes in relation to this topic, but that from the participants' reports on their practices, these were incorrect and included condom application only at the time of penetration, whereas according to these authors, "the most appropriate procedure would be to use it throughout the sexual intercourse, starting from before any genital contact" (p. 15). Although this study focused on contraception, it also covered STI/AIDS use with regard to condom use. In this respect, practically all the participants stated that it was necessary to use condoms during all sexual intercourse: a significant number of them $(65.1 \%)$ said that they would not have sexual intercourse if the partner did not want to use a condom, although some of them (17.6\%) said that they would have intercourse without protection if they knew the partner well. In addition, $46.1 \%$ of the university students considered that condoms did not interfere with sexual intercourse and $23.1 \%$ stated that they caused diminished sexual pleasure.
The study by Marta et al. (2008) aimed to delineate the profile of undergraduate nursing students with regard to AIDS. In this study, the majority of the participants presented correct information about the forms of HIV transmission. Condoms were prominent as the preventive method most often mentioned (91.7\%). Among the sexually active participants, $58.8 \%$ said that they had used a condom in their first sexual intercourse. However, this measure was dismissed by $48.5 \%$ after a month of dating, when the relationship was considered to be steady and without risks.

Other studies have concentrated more specifically on behavior relating to condom use as an STI/AIDS preventive strategy. Among these, the article by Saldanha et al. (2008) described the sexual behavior and "AIDS vulnerability profile" among students aged 13 to 18. According to the researchers, early sexual initiation with an older partner and having several partnerships were factors that increased vulnerability and were worsened through non-systematic condom use. In this regard, 54\% seemed to state that they always used condoms ${ }^{5}$. The study investigated the young people's knowledge only in relation to contraceptive methods: $56 \%$ of them said that they used contraception, and condoms were cited most frequently (64\%).

Likewise, Carvalho et al. (2007) conducted a study among young adults aged 18 to 50 years $^{6}$ frequenting night clubs. In this context, the researchers investigated not only safe sex practices but also whether the participants were carrying condoms with them at the time of the survey, and how they were packed. They found that $58.8 \%$ of the interviewees said that they always used condoms and $38.4 \%$ were carrying condoms

\footnotetext{
In the article by Saldanha et al. (2008), there is a mismatch in some information relating to the frequency of condom use, between what is presented in a table and in the abstract.

6 Although it is uncommon to use the term "young people" for a group of this age range, it seems that the researchers used this term based on the fact that more than half of the participants were between 18 and 23 years of age, such that the mean age was 22.56 , the mode was 18 years and the median was 21 years.
} 
with them at the time of the survey. Among the latter, $40.7 \%$ were carrying them in their wallets. It was observed that there was a relationship between the packing and packaging conditions, such that all the condoms that were crushed were found in wallets. Prominent among the reasons for not using condoms were use of hormonal contraception (43.2\%) and complaints that condoms diminished the pleasure $(29.6 \%)$.

Matos et al. (2009) also concerned themselves with behavior, but focusing on factors that motivated safe sex practices among young adult students aged 18 to 19 years. Thus, they sought to identify the antecedents of the intention to use condoms among the participants and concluded that formation of the intention was dependent not so much on attitudes but, rather, on social norms and on perceptions of behavioral control, i.e. personal belief regarding the degree of ease in adopting this behavior. In this regard, the moral obligation to use condoms was expressed more by the men than by the women. However, the women were seen to be less susceptible to the temptation to have sex without a condom and manifested less difficulty in preventing that sex happens in this conditions. In relation to social pressure, doctors and mothers were highlighted as the most significant influences on the intention to use condoms, especially among the women.

Leite et al. (2007), in turn, emphasized the process of choosing the method for contraception and prevention of STI/AIDS among university students within the field of healthcare. They found that these individuals almost unanimously chose condoms as the contraceptive method. Among the boys, this choice was explained especially by practicality and low cost; and among the girls, by the absence of side effects. However, in a general manner, such a choice did not appear to be linked to STI/AIDS prevention, which draws the attention of the authors because it is the prospect of future healthcare professionals.

Healthcare professionals were also investigated by Oliveira et al. (2008), who ascertained the level of knowledge regarding female condoms and the dynamics of promotion this method, among doctors and nurses at public reference institutions for STI treatment. The re- sults indicated that there was a knowledge deficit in relation to the basic characteristics of female condoms and how to put them on among the professionals in both categories. However, knowledge about the steps involved in putting condoms on was shown to be associated with females. Furthermore, it was seen that there was little promotion of the use of female condoms, and this was justified by these professionals on the basis of the high price, lack of availability at healthcare units, lack of knowledge and lack of adherence among women, unlike the greater access to male condoms.

The study by S. M. Barbosa et al. (2008) covered the parents of adolescent students at public schools. These researchers investigated behavioral change stages in relation to communication with their children regarding sexuality and measures for preventing STI/AIDS. The results indicated that most of the parents talked to their children about this, or were interested in doing so. However, some of them expressed difficulty in this, especially regarding the need for greater clarification regarding measures for preventing STI/AIDS or unwanted pregnancy.

The behavior of elderly people in relation to STI/AIDS prevention was studied by Laroque et al. (2011), who identified a variety of factors that contribute towards the low adherence to condom use among this segment of the population, especially during the post-reproductive period. These factors included embarrassment in talking about sexuality and proposing condom use; resistance to and prejudice against condoms, given that this segment of the population started their sexual lives prior to the AIDS epidemic; and the fact that sexual practice at this stage of life imply certain limitations, which is added using condoms. Moreover, according to the authors, prevention aimed towards this population comes up against the difficulty that healthcare professionals have in dealing with the sexuality of elderly people.

Lastly, among the texts analyzed, there was the preliminary note by Nicolau and Pinheiro (2010), who communicated about a study to be conducted among female convicts regarding their knowledge, attitudes and practices relating to male and female condoms. 


\section{Studies on Specific Contexts}

Among the studies along this strand, which were characterized by covering specific contexts with reference to sociocultural factors, the attention given to women and to gender relations within the contexts investigated can be highlighted. Different data-gathering techniques were used: Riscado, Oliveira and Brito (2010) and Reis and Bernardes (2011) used the technique of focus groups; Moura, Lima, Farias, Feitosa and Barroso (2009) conducted interviews and participant observation; and Sousa, Espírito Santo and Motta (2008) put these techniques together in their investigation.

M. C. P. Sousa et al. (2008) circumscribed the context of adult women in steady conjugal relationships who were living in a low-income region on the periphery of Teresina, state of Piauí. To identify these women's vulnerability to HIV, the researchers looked into whether they were using condoms, the gender relationships that they experienced with their partners and the actions implemented within the Family Health Program (FHP) [Programa de Saúde da Família] in this context. The researchers perceived that the majority of the women did not make continuous use of condoms, especially because of difficulties relating to negotiation of this practice with their partners; condom use was more early included in sexual practice when envisaged as contraceptive. In relation to the assistance provided by the FHP to these women, the researchers emphasized that this was restricted to health education on women's health, centered on prenatal follow-up and on measures for reduction of gynecological cancer. Thus, the healthcare teams did not incorporate discussion about sexuality and gender relations, which worsened these women's vulnerability in this context.

In the same direction, Riscado et al. (2010) conducted a study among women in remnant communities of former slaves, known as Quilombos, in the state of Alagoas, and found that these women had a significant lack of knowledge of the importance of condom use, along with resistance to the adoption of this practice and difficulties related to the need for their partner's permission to do so. According to these researchers, the high degree of vulnerability of these women to STI/AIDS was linked to their context, marked by precarious living conditions, high levels of occurrence of domestic violence and racism (experienced in different contexts of social and institutional relationships), difficulties in accessing healthcare services, lack of any effective healthcare policy and lack of educational work in such communities.

The study by Moura et al. (2009) also focused on women, within a scenario of prostitution and poverty in the interior of the state of Ceará, in which there were a variety of obstacles hindering prevention. The researchers noticed that the prostitutes investigated faced difficulties in acquiring condoms, such that their use became the client's responsibility. In general, condoms ended up being used only in intercourse with unknown and recent clients, and were dispensed with in intercourse with old and known clients, and also with steady partners (sometimes married or in relationships with other women). Moreover, the context of a prostitute's submission to a client gives legitimacy to demands by clients for sexual intercourse without a condom, which may even place the sex worker's health in jeopardy if she does not consent to this practice.

On the other hand, C. B. Reis and Bernardes (2011) looked into the context of penitentiaries, to investigate strategies adopted for preventing infection and the spread of STI/AIDS. They noticed that the male and female participants, inmates from public jails in cities in the state of Mato Grosso do Sul (who interacted with the community through family members, visitors, prison officers and in their different experiences of recidivism), recognized the importance of prevention and were able to indicate the main preventive methods, among which they highlighted consistent use of condoms as the most efficient method. However, they tend to use them only sporadically, due to difficulty in its acquisition, lack of counseling from the local healthcare team on this topic and lack of interest among the inmates themselves, which they explained through their involvement with steady partners. The researchers drew attention to the precarious healthcare provided for the male and 
female inmates, which was correlated with society's prejudice and discrimination.

\section{Studies on Senses and Meanings}

In this research strand, the articles rely on different concepts and theoretical perspectives for understanding the senses and meanings attributed to the use of condoms as a prevention strategy for STI/AIDS. Here too, the resource to gender issues was recurrent, for understanding aspects related to the use of condoms, especially within the scope of emotional-sexual relationships.

Sampaio et al. (2010) and Sampaio et al. (2011) made use of the theoretical-methodological model of discursive practices and investigated STI/AIDS prevention within the context of care provided for adolescents at Family Health Units. The first study (Sampaio et al., 2010) discussed the production of meanings by adolescents and healthcare teams regarding gender and sexuality and their implications for STI/AIDS prevention. The researchers identified macho concepts among the adolescents, along with lack of knowledge in relation to the forms of STI/ AIDS prevention. More specifically, they have highlighted production of meanings in relation to romantic love, fidelity and monogamy among young people and adults, both men and women, which were correlated with a supposition of protection that would make it unnecessary to use condoms in relationships conformed from these elements. Among the health professionals, they noticed a "significant difficulty in working on sexuality during adolescence, such that it was fundamental to rethink bio reductionist discourse and banking education as strategies for coping with STI/AIDS" (p. 173).

On the other hand, the article by Sampaio et al. (2011) focused on the vulnerability of young women to STI/AIDS and especially, the meanings attributed to gender relationships in configuring the difficulties that adolescents face in negotiating condom use with their partners. Among these senses, the researchers highlighted that the initiative of proposing condom use was identified as the man's prerogative; the estrangement towards girls proposing sexual intercourse or the use of condoms and "blame" on girls due to cases of STI or unplanned pregnancy.

The study by Madureira and Trentini (2008b) used the notion of attitude and looked at the perspectives of heterosexual men in relation to condom use. The results indicated that in STI/AIDS prevention, "issues relating to beliefs, myths, health stereotypes and the characteristics of relationships between men and women were tangled together" (p. 1807). Among the justifications for the recognized male resistance to condom use, the researchers identified the notions that condoms are bothersome, imply interruption of sexual foreplay, reduce pleasure and cause fear of losing erection or of poor sexual performance. In addition, they highlighted that the central motive for not using condoms was the association that had been established between preventive practice and mistrust or infidelity.

From these findings, these authors produced an essay (Madureira \& Trentini, 2008a) in which they correlated STI/AIDS prevention with the configuration of affective-sexual relationships within a heterosexual conjugal context. In this regard, they drew up three models of relationships, in which are articulated in different ways the elements of love, desire, pleasure and fidelity. Each model was tied to a particular construction of masculinity and had different repercussions with regard to adoption of safer sexual practices. Although this formulation presented closed-off models that categorized individuals' participation in relationships, it produced findings that were the same as in other studies, such as the notions that condoms as a preventive method are considered to be unnecessary in steady relationships in which fidelity is presumed, and that they are used especially in casual intercourse, i.e. extramarital sex in this case.

In turn, Maksud (2009) investigated the social representations of serodiscordant couples in relation to sexual practices and condom use. This author took the view that such representations conformed logics that generally was not accompanied by the official discourse regarding prevention. From an attempt to "understand the meanings of sexual behavior and the social senses of desire" (p. 355), this author identified con- 
structs such as the relativization of disease and of the risk of seroconversion and the difficulties relating specifically to the situation of conjugality, such as the unpredictability of sexual practices and the rationale, expressed by men, that they did not like to use condoms because they want "to feel the skin". In this regard, it seems to occur a process of routinization of intimacy and a suspension of safer sex.

In the same direction, R. K. Reis and Gir (2009) conducted a study among individuals with HIV/AIDS who were living with serodiscordant partners and who were attended at a public outpatient referral service for HIV/AIDS patients. Among the meanings identified in the participants' statements, an idea of naturalization of HIV/AIDS infection as a disease manage able by medications was outlined, along with a belief that antiretroviral therapy and, particularly, undetectable viral load prevent the risk of virus transmission, and a feeling of invincibility that arose with increasing length of time that the couple had been together. These constructs appear as factors interfering in the maintenance of condom use, and therefore increased the vulne-rability of the seronegative sexual partner to HIV infection.

Like in the above two studies, the article by Maliska et al. (2007) discussed prevention regarding relationships in serodiscordant couples. However, in this study, the discussion was undertaken from the perspective of feminization of the AIDS epidemic and the "vulnerability of women". The results indicated that the participants, who were users of a healthcare facility specialized in STI/AIDS, believed that they were protected in steady relationships and that, even after becoming infected, faced difficulty in negotiating condom use with their partners. Going against the healthcare team's prescription advice to use condoms, resistance to this preventive method emerged among the men, sustained by the belief that they would not transmit to their seropositive female partners any infection that was more serious than what the partners already had, through the "myth" that women do not transmit HIV to men and through possible transgressive motivation to the regulation imposed by prevention.
Lastly, Gomes et al. (2011) proposed to identify the perceptions of young heterosexual couples aged 20 to 27 years comprising students in an undergraduate nursing course and their male or female partners, regarding their use of female condoms and associated factors that favor or hamper the adoption of this practice routinely. The researchers concluded that the participants know the efficiency of this method, but emphasized the difficulty for women to negotiate its use, the little dissemination about female condoms and its high cost. In relation to its use, the participants said that they were practical, reliable and gave pleasure but on the other hand, there was pain, discomfort and a grotesque appearance. Lack of familiarity and lack of knowledge seemed to be the main triggering factors for difficulties.

\section{Studies on Activities}

Firstly, we present studies that looked into activities relating to HIV/AIDS prevention as the subject of the investigation or report. Then we describe a study that used condom promotion activities as part of a specific investigation.

Among the first group is a description of a community-based intervention for control of STI/AIDS in the Amazon region, presented by Benzaken et al. (2007). This intervention program was developed within the scope of the Brazilian National Health System [Sistema Único de Saude (SUS)], with the participation of researchers, government officials, health professionals and the community. Its actions ranged from local data collection (dynamics of prostitution, sale of condoms and behavioral characteristics) to STI prevention and care actions within the public healthcare system and capacitation provided for sex workers, along with assessments of the actions and the process. A variety of positive results from the experience were reported. Regarding condoms, it was seen that there were general increases in sales and in use among sex workers, along with reduction of the incidence of bacterial STIs and stabilization of the occurrences of HIV/ AIDS and congenital syphilis infection.

Also in this regard, the article by Ferraz and Nemes (2009) presented an assessment of 
the implementation of STI/AIDS prevention activities in a Family Health Unit. According to the authors, the technological profile of the unit investigated resembled that of the traditional primary care services in Brazil, with limited potential to establishment of the principle of comprehensiveness. Along these lines, the prevention activities implemented (including dispensing of condoms) were seen to be fragmented and "emptied of important technological directions, such as dialogue and attention to users' singularities" (p. S249).

The study by Borba (2011) refers to the analysis of interventions, in which activists from a non-governmental organization distributed condoms among transvestite who prostitutes. With emphasis on the relationship between language and interactional construction of social identities, the researcher examined the discursive dynamics that emerged in interactions between the people providing the intervention and the transvestites and argued in favor of the importance and usefulness of comprehending these elements in prevention work among marginalized groups and fighting the spread of STI/AIDS.

A. A. Sousa et al. (2009) presented a short report on a project that they were conducting every three months in Suzano, state of São Paulo/SP. It is a themed soiree aimed at artists, teachers and community members in general, in which artistic and musical activities are linked to the provision of condoms and informational materials that foster discussions about sexuality in the light of safer sexual practices. This event encouraged reading and erotic art, along with dissemination and expansion of access to health services.

In turn, the study by Albuquerque and Villela (2011), among women at a Family Health Unit on female condoms, presented an intervention as part of the study. In this, the data-collection itself is combined with educational activities, experimentation with the female condom at a nursing consultation office and use at home. The results showed that after the initial perplexity regarding female condoms, most of the users reported that they gained a positive impression, although they expressed difficulties in relation to handling and introduction, due to excessive lubrication. Although the focus of the study was on contraception, STI prevention came up as an important motive for choosing this method. In a general manner, however, use of female condoms was hindered by difficulties in negotiating this with partners.

\section{Studies of Literature Review}

Among the articles analyzed, only two of them fitted into this category. The article by Brisighelli et al. (2009) presented, in abbreviated form, a review on the efficacy of condoms as a method for STI prevention. From the studies surveyed, the authors emphasized that condoms do not provide a completely effective barrier, given that their material is permeable to small viruses, that they do not cover the entire perineal region and that transportation and storage may alter their quality. In addition, lack of knowledge of and familiarity with correct use of this method is an important factor in diminishing their efficacy.

In another direction, the review produced by Rebello et al. (2011) emphasized the relationship between men and AIDS prevention. From the studies found, the authors point out, among other things, the centrality of condoms in prevention. However, this element appears in the literature especially from the questioning of the acceptance of its use by men. In this regard, the authors emphasized the consensus that the reasons for not using condoms are structured from models of beliefs present in the social imaginary. Over the course of their review, the authors identified different constructs that are characteristic of these models: power relations between men and women; the association of condoms with illicit sex, and therefore with infidelity; the idea that condom does not fit with marriage; that condoms may be waived in relationships involving effective commitment and the belief that condom use can harm to men, because it retains something that should be released, and for the women because it prevents the uterus from being moistened by the semen; the belief that women cannot transmit HIV; the refusal to use a condom 
as a demonstration that the risk is not feared; and the association between satisfaction in anal sex and the identity of men who have sex with men. Lastly, these authors argue that this discussion progresses as it articulates the role of such preventive measure itself with the meanings associated with condoms.

\section{By Way of Discussion: Highlights from the Literature and Considera- tions about the Strands of Research}

Despite the diversity of studies on condom use as a strategy for HIV/AIDS prevention, we can identify certain highlights, notably the attention given to young people and to gender issues. Studies along these lines can be comprehended in the light of the emphasis given to young segments of the population in relation to prevention policies (Paiva et al., 2008) and in the light of the centrality of discussions regarding "negotiation" on condom use between the partners (Madureira \& Trentini, 2008a, 2008b). Nonetheless, these are two highlights of different natures.

The first of these is directed towards a population segment and predominates among the more quantitative studies. It can be noted that the group named young people (or adolescents) was defined in different ways in these studies, with different age limits and covering participants who were both within and outside of the educational system.

Regarding the other groups present in the literature examined, we emphasize that there was a scarcity of studies discussing condom use among men who have sex with men, injectable drug users and sex workers, which are the groups in which the HIV and AIDS epidemic in Brazil has remained concentrated since its beginnings (Malta et al., 2010). In this regard, we can highlight that, among young men, homosexuals have been shown to be the segment most affected by HIV over the last few years (MS, 2011). Likewise, only a few studies have encompassed the context of prostitution and male commercial sex workers have not been included. Moreover, there has been little or no consideration of other social markers of difference in defining the parti- cipants and delineating the studies, such as race/ ethnicity (investigations on black or indigenous populations, etc, are scarce or nonexistent).

On the other hand, the second highlight is thematic and relates to gender relations that have set up certain challenges to the adoption of condom use, given the relational nature of sexual practices, the dimension of power that articulates gender relations and cultural values associated the constructions of masculinity and femininity. This highlight appears more clearly in investigations of qualitative design: both in studies that directly discuss the relationships between couples and in studies conducted specifically among men or among women. In an incipient manner, gender relationships have been linked to other relevant social issues, such that they can be found in studies on serodiscordant couples, women from remnant hinterland communities of former slaves, poor women, young women and female prostitutes.

Gender relations emerged as an important determinant of the HIV/AIDS epidemic at the time when the trend towards feminization of the epidemic was identified at the beginning of the 1990 s, with the growth in the numbers of AIDS cases in Brazil and around the world (MS, 2009). Within this sphere, it is important to be attentive towards the complexity of such social configurations, because of the risk of reproducing clichés that are often seen in discussions on gender, which make it difficult to reflect on nuances and circular arguments regarding the relationship between gender and sexuality, and more specifically, regarding condom use. In this manner, we recall the criticism and relativization of the idea of negotiation of condom use within the sphere of unequal gender relations, made in the 1990s by R. M. Barbosa, Villela and Uziel (1995). These authors questioned the simplification of the complex equation established between the ideas of negotiation and the adoption or not of safer sexual practices.

In relation to other topics that were covered less notably or were absent among the set of studies examined, the list of issues that could be and deserve to be considered within the scope of this subject is endless. Among these, we can highli- 
ght the lack of reflection within Brazilian academic production on the topic of "condom fatigue" and the need for more in-depth discussions on the role of health services in this context, the relevance of which is marked by recognition of the programmatic dimension of vulnerability to HIV/AIDS and, in this regard, the support available for prevention. Furthermore, especially in studies on senses and meanings, it would be useful to deepen the reflections on medicalization of condom use and of the discourse of prevention $^{7}$, along with investigation of the possibility of bringing this discourse closer to the dimension of erotica, which was suggested by Parker (1994), for example.

With regard to the six research strands of these studies, we emphasize that the categorization thus produced does not exhaust the possibilities for joint analysis on the texts used. In addition, the characterization of these strands was not totally homogenous, considering that although some articles fitted better into one type of study, they could present some characteristics of another strand. So it is with the article by Cruzeiro et al. (2010), which was placed in the group of epidemiological studies, but operates, however, a typical logic of studies on knowledge and behavior. This intersection seemed to occur most clearly in relation to the debate on senses and meanings, which was present secondarily in the articles by Ribeiro et al. (2011), among the epidemiological studies; M. C. P. Sousa et al. (2008), among the studies on specific contexts; and Matos et al. (2009) and Saldanha et al. (2008), among the studies on knowledge and behavior.

Although all the studies analyzed had in common the purpose of producing knowledge that would be useful for coping with HIV/AIDS within the field of prevention, and specifically by means of condom use, each strand of research presented its own logic regarding the manner of looking into the question and produced a

\footnotetext{
"Medicalization of condom use and preventive discourse" is understood here in the sense used in discussions on "social medicalization"; refer to: Tesser (2006).
}

specific type of knowledge. From a panoramic viewpoint, we can emphasize that these different approaches are complementary, given that all the studies add information to the literature. Nonetheless, it is fundamental to be attentive to the limits that exist in relation to these forms of producing knowledge and to the care needed in conducting studies with certain designs, with regard to reading and using the conclusions presented.

In this regard, it is worth indicating that epidemiological studies have recognized relevance in terms of the coverage of the data produced (for example, these are the studies that make it possible to estimate condom use in the population) and contribute towards indicating the priorities in drawing up preventive actions and policies. However, the construction of such knowledge entails successive processes of conceptual abstraction, which ensure formal and mathematical handling of great precision, at the cost of moving away from fundamental aspects of the reality to think prevention (Ayres, 2002). The history of the production of knowledge in the field of AIDS has shown the danger of making this separation, especially with regard to using a probabilistic association [for example, the indication in the study by Berquó et al. (2008) that people in the Pentecostal religion use condoms less frequently that do those without religion or those who follow other religions] to generalize a given characteristic, thereby producing identities and labeling people and hence guiding the design and implementation of preventive actions (Ayres et al., 2006).

On the other hand, studies on knowledge and behavior represent an attempt to identify and/or structure information and practices that are useful for HIV/AIDS prevention. These seem to take techniques of relevance for preventive work as their baseline: for example, they seek to identify which information is less well-known and needs to be better disseminated, or which guidance is more effective in educational activities. However, this way of producing knowledge may incur in adopting naturalized or normative criteria over sexual practices, in taking, as a parameter, knowledge and behavior considered correct 
regardless the contexts of intersubjectivity in which personal identities, values and practices are concretely and dynamically constituted.

As pointed out by Paiva (2000), the behavioral conception of prevention, although it represented an overture towards working with information and counseling regarding sexual practices (more or less) safe, especially in relation to condom use, this tends to disregard the social context. In this, behavioral change is taken to be an individual responsibility and an intentional process among subjects who have been "convinced" by experts of their needs.

In a particular manner, studies following this research strand that have identified that most young people have knowledge about AIDS and about the ways of preventing it, especially condom use (Alves \& Lopes, 2008; Leite et al., 2007; Marta et al., 2008), lead us to conclusions that favor dissemination of information and guidance on prevention, and to the working on education for sexuality. However, this situation is contradicted by studies such as the one by Sampaio et al. (2010), which is categorized as a study on senses and meanings, and which found that adolescent girls and boys frequently did not know about STIs and prevention, whereas healthcare professionals believed that these young people possessed such knowledge but, despite this, did not maintain preventive behavior through irresponsibility, thereby making preventive work impossible among this population group. In this regard, we can point out that there is a need to distinguish between access to information and the real possibility of communication among the subjects involved in preventive practice, with a view to transforming the contexts of intersubjectivity that shape vulnerability to HIV/AIDS (Ayres, França, Calazans, \& Saletti, 2003).

Studies on specific contexts and studies on senses and meanings, which are governed by the logic of understanding about the use of condoms, seem to respond to the perception that acquisition of knowledge regarding STI/AIDS and condom use is not enough for practicing protected sex (which was mentioned by Alves \& Lopes, 2008, for example), since such practices are not detached from the contexts in which they take place and the social constructs in which they operate. In this regard, going beyond condom use and (re)cognition of its importance, these studies enable advances in knowledge and reflection regarding the implications of this practice for the subjects involved, and what this represents and gives rise to in certain situations.

Nevertheless, consideration of the specific contexts and the construction of senses and meanings, by themselves, do not ensure production of a useful comprehensive totality on the difficulties and possibilities relating to condom use as an HIV/AIDS prevention method. Along these strands, there is a danger of being caught in the fallacy of dealing with these matters simply as instruments for "convincing" people better regarding condom use, without actually seeking to merge horizons ${ }^{8}$ with such contexts and constructs.

Also in relation to studies on specific contexts, it should be borne in mind that these generally operated with a logic in which the subjects are comprehended as collective subjects, as a function of the conditions of their surroundings. In this case, attention is needed in order not to lose the perspective of subjectivity and the singular manner in which individuals relate to such conditions. It is particularly important in the process of understanding, to be able to observe the way in which different intersubjective contexts shape identities and practical horizons that are central to the establishment of dialogues that can effectively promote changes in relationships and reduction of vulnerabilities.

The relevance of studies on activities is demarcated by registering experiences and the possibility of articulating studies with interventions. This is especially important in a field such as prevention of STI/AIDS, which remains close to practice and whose actions, especially actions to promote condom use, are under construction, given that significant challenges still exist and that what has been accumulated comprises some lessons, as shown by Ayres (2002) and Paiva (2000).

8 For a discussion on the concept of merging of horizons, refer to: Ayres (2008). 
Among all the studies examined, we need to highlight that few of them had focused on the far from insignificant challenge of how to promote condom use. Taking into consideration, among the studies on activities, only the reports and analyses on experiences, it can be seen that there were few initiatives dedicated to describing and/or evaluating technological proposals regarding how to promote condom use in given contexts. It seems to us that this is a field that needs to be better explored, based on descriptions of technological innovations relating to practices and articulating with in-depth reflection on the theoretical basis and the difficulties and potentials identified in different contexts and with different population groups. In this regard, considering the centrality of condom use within policies on prevention of STI/AIDS in the Brazilian context, this is a fundamental type of knowledge production with regard to the field of health practices.

In a general manner, studies of literature review are opportunities for gathering, synthesizing and evaluating knowledge that has been produced regarding a given topic. In relation to condom use as a strategy for STI/AIDS prevention, such studies have been scarce over the last five years. Considering that the two studies that we identified within this strand of research are related to specific themes (efficacy of condoms and prevention among men), we note that there is a lack of broader work of systematization of studies on condom use as a preventive method, which is a topic central to the policies for coping with STI/AIDS in Brazil.

Directed toward overcoming this gap, this essay represents an attempt to provide a critical overview of studies on this topic, which may contribute towards comprehending how condom use and HIV/AIDS prevention have been thought and how research and practices within this field have been put into operation theoretically and methodologically. In this regard, our intention was that this study should make it possible to conduct new analyses and undertake new approaches relating to this topic.

It is clear that this study presents some important limitations, such as the time cutoff used in selecting the articles and the criteria that could not be incorporated in the analysis, such as characterization of the authors and the institutional affiliation of possible groups of researchers. Investigating of these matters could, for example, make it possible to pose the question of what seemed to us to be a concentration of published papers on this topic within certain areas, notably public health and nursing, thus highlighting the scarcity of articles in journals of psychology. The concentration of such published papers within a restricted area of the field of health sciences diverges from the understanding that the actions for reducing vulnerability to STI/AIDS should not be restricted to the institutional sphere of health and should be expanded in their scope of action in an interdisciplinary and intersectoral manner, with a view to transforming the contexts of vulnerability (Ayres et al., 2003).With regard to psychology, it can also be considered, in particular, that, among the authors of the articles analyzed, there were researchers and professionals with training in psychology and that some of the articles were anchored in theoretical reference frameworks originating from psycholo$\mathrm{gy}^{9}$. In the absence of systematic analysis in this respect, we can only ask why the psychologists who investigated prevention of STI/AIDS have sought or found more space in journals within other fields.

Furthermore, lack of expansion of the scope of this research by the use of other databases constitutes a limitation because of the restrictions found in the portal that was used for searching for articles, especially with regard to the mechanisms for searching for and retrieving articles through the links that are made available in the portal.

Lastly, it should be borne in mind that because of the large quantity of studies produced about themes related to the condom use, we chose to direct the focus of the present work towards HIV/AIDS prevention, and did not include some specific issues of importance to discussions re-

9 For example, the studies on behaviors or behavioral change and on discursive practices, which are presented in the Results section. 
garding contraception and prevention of other STIs.

\section{Final Remarks}

The analysis undertaken in this article has allowed us to come to some conclusions regarding the academic production on the use of condoms as a strategy for HIV/AIDS prevention. Firstly, the literature on this topic can be described as concentrating on investigating some groups of participants and on discussing some topics in particular, while leaving out some subjects, contexts and issues that have been shown to be important in coping with the AIDS epidemic and in the adoption of preventive practices. This diverges from the impression that the literature is wide-ranging and diverse, which might be supposed when looking at the amount of studies published that address this subject. In this regard, it is opportune to develop new studies that analyze and create panoramas regarding this production, so as to delineate the paths that need to be traced out or strengthened, in investigating the field of prevention of HIV/AIDS.

Another characteristic observed was that the literature studied was of diffuse nature in regard to the logic of the production of knowledge. Despite the inherent value of a production that comprises different theoretical-methodological bases, we found an interweaving of approaches and directions, which at some moments seemed confusing. We saw this in identifying the permanence of studies based on behavioral approaches towards prevention, which linked this to conditions of vulnerability that, in the history of operational concepts of investigations within the field of AIDS, mark criticism and surpassing of the individualistic perspective of this first approach.

We found a variety of references to vulnerability to HIV among the set of studies analyzed, ranging from a more superficial usage of the specific terms of this framework to a more substantial appropriation of this referential framework, including intermediate positions of linkage between this and the notion of risk, or between this and a behavioral approach. We assume, on the one hand, that the formulations and termi- nology of the theoretical framework of vulnerability and, in a certain way, its legitimacy has a broad reach [which, as seen earlier, has even been recognized by the national public policies (MS, 2009)]. On the other hand, we noted that a large number of different directions have been taken in the production of knowledge on this subject, which indicates that there is a need for greater debate and epistemological and methodological maturation in relation to the theoretical framework of vulnerability, as well as with regard to the theoretical and methodological frameworks used in studies on condom use as an HIV/AIDS prevention strategy.

We see this maturation process as a task that cannot be delayed and as a historical commitment that is necessary for coping with the AIDS epidemic, in the following senses: (a) recognizing the population groups that are most affected; (b) seeking to comprehend their complex susceptibilities socially configured; and (c) designing vigorous, creative and potent approaches that are capable of involving individuals and groups so that they can appropriate and mobilize in an authentic manner in order to find practical alternatives that make it possible to overcome the conditions that shape their vulnerabilities.

\section{References}

Adam, B. D., Husbands, W., Murray, J., \& Maxwell, J. (2005). AIDS optimism, condom fatigue, or self-esteem? Explaining unsafe sex among gay and bisexual men. The Journal of Sex Research, 42(3), 238-248.

Albuquerque, G. A., \& Villela, W. V. (2011). Uso do preservativo feminino como método contraceptivo: Experiências de mulheres em uma Unidade Básica de Saúde no município de Juazeiro do Norte - CE. Revista de APS - Atenção Primária à Saúde, 14(2), 185-196.

Alves, A. S., \& Lopes, M. H. B. M. (2008). Conhecimento, atitude e prática do uso de pílula e preservativo entre adolescentes universitários. Revista Brasileira de Enfermagem, 61(1), 11-17.

Ayres, J. R. C. M. (2002). Práticas educativas e prevenção de HIV/Aids: Lições aprendidas e desafios atuais. Interface - Comunicação, Saúde, Educação, 6(11), 11-24. 
Ayres, J. R. C. M. (2008). Para comprender el sentido práctico de las acciones de salud: contribuciones de la hermenéutica filosófica. Salud Colectiva, 4, 159-172.

Ayres, J. R. C. M., Calazans, G. J., Saletti, H. C., Filho, \& França, I., Jr. (2006). Risco, vulnerabilidade e práticas de prevenção e promoção da saúde. In G. W. S. Campos, M. C. S. Minayo, M. Akerman, M. Drumond Jr., \& Y. M. Carvalho, Tratado de Saúde Coletiva (pp. 375-417). São Paulo, SP: Hucitec.

Ayres, J. R. C. M., França, I., Jr., Calazans, G. J., \& Saletti, H. C., Filho. (2003). O conceito de vulnerabilidade e as práticas de saúde: Novas perspectivas e desafios. In D. Czeresnia (Org.), Promoção da saúde: Conceitos, reflexões e tendências (pp. 121-143). Rio de Janeiro, RJ: Editora da Fundação Oswaldo Cruz.

Ayres, J. R. C. M., Paiva, V., \& França, I., Jr. (2011). From Natural History of Disease to Vulnerability: Changing concepts in contemporary public health. In R. Parker, \& M. Sommer (Eds.), Routledge Handbook in Global Public Health (pp. 98-107). New York: Routledge.

Barbosa, R. M., Villela, W. V., \& Uziel, A. P. (1995). Entre a vontade e a necessidade: Negociação sexual em tempos de aids. Physis - Revista de Saúde Coletiva, 5(1), 99-107.

Barbosa, S. M., Costa, P. N. P., \& Vieira, N. F. C. (2008). Stages of change in parents' discussions with their children about HIV/Aids prevention. Revista Latino-Americana de Enfermagem, 16(6), 1019-1024.

Benzaken, A. S., Galbán Garcia, E., Sardinha, J. C. G., Pedrosa, V. L., \& Paiva, V. (2007). Intervenção de base comunitária para a prevenção das DST/Aids na região amazônica, Brasil. Revista de Saúde Publica, 41(Supl. 2), 118-126.

Berquó, E., Barbosa, R. M., Lima, L. P., \& Grupo de Estudos em População, Sexualidade e Aids. (2008). Uso do preservativo: Tendências entre 1998 e 2005 na população brasileira [Trends in condom use: Brazil 1998 and 2005]. Revista de Saúde Pública, 42(Supl. 1), 34-44.

Borba, R. (2011). Interconexões entre Linguística Aplicada e práticas de atenção à saúde: Linguagem e identidades na prevenção de DSTs/ Aids entre travestis profissionais do sexo. Physis - Revista de Saúde Coletiva, 21(4), 1369-1400.
Brisighelli, A. B., Neto, Araújo, A. C., Doher, M. P., \& Haddad, M. A. (2009). Revisão sobre a eficácia do preservativo em relação à proteção contra doenças sexualmente transmissíveis e gestação. Diagnóstico e Tratamento, 14(3), 123-125.

Carvalho, A. L. S., Bezerra, S. J. S., Leitão, N. M. A., Joca, M. T., \& Pinheiro, A. K. B. (2007). Porte, acondicionamento e utilização de preservativo masculino entre jovens de Fortaleza: Um estudo descritivo. Online Brazilian Journal of Nursing, 6 .

Costa, L. C., Rosa, M. I., \& Battisti, I. D. E. (2009). Prevalence of condom use and associated factors in a sample of university students in southern Brazil. Cadernos de Saúde Publica, 25(6), 1245-1250.

Cruzeiro, A. L. S., Souza, L. D. M., Silva, R. A., Pinheiro, R. T., Rocha, C. L. A., \& Horta, B. L. (2010). Comportamento sexual de risco: Fatores associados ao número de parceiros sexuais e ao uso de preservativo em adolescentes. Ciência \& Saúde Coletiva, 15(Supl. 1), 1149-1158.

Ferraz, D. A. S., \& Nemes, M. I. B. (2009). Avaliação da implantação de atividades de prevenção das DST/AIDS na atenção básica: Um estudo de caso na Região Metropolitana de São Paulo, Brasil. Cadernos de Saúde Publica, 25(Supl. 2), s240-s250.

Gomes, V. L. O., Fonseca, A. D., Jundi, M. G., \& Severo, T. P. (2011). Percepções de casais heterossexuais acerca do uso da camisinha feminina. Escola Anna Nery Revista de Enfermagem, 15(1), 22-30.

Joint United Nations Programme on HIV/AIDS. (2012). UN Secretary-General issues recommendations to bolster AIDS response in order to meet 2015 targets [Press release]. Retrieved May 10, 2012, from http://www.unaids.org/en/ media/unaids/contentassets/documents/pressrelease/2012/04/20120430 PR SG Report en.pdf

Kalckmann, S., Farias, N., \& Carvalheiro, J. R. (2009). Avaliação da continuidade de uso do preservativo feminino em usuárias do Sistema Único de Saúde em unidades da região metropolitana de São Paulo, Brasil. Revista Brasileira de Epidemiologia, 12(2), 132-143.

Kalichman, A. O. (1993). Vigilância epidemiológica de AIDS: Recuperação histórica de conceitos e práticas (Dissertação de mestrado, Faculdade de Medicina, Universidade de São Paulo, SP, Brasil). 
Laroque, M. F., Affeldt, Â. B., Cardoso, D. H., Souza, G. L., Santana, M. G., \& Lange, C. (2011). Sexualidade do idoso: Comportamento para a prevenção de DST/AIDS [Sexuality of the elderly: Behavior for the prevention of STD/AIDS]. Revista Gaucha de Enfermagem, 32(4), 774-780.

Leite, M. T. F., Costa, A. V. S., Carvalho, K. A. C., Melo, R. L. R., Nunes, B. M. T. V., \& Nogueira, L. T. (2007). Saber e prática contraceptiva e prevenção de DST/HIV/AIDS em universitários da área da saúde. Revista Brasileira de Enfermagem, 60(4), 434-438.

Lima, F. S. S., Silva, M. J. G., Godoi, A. M. M., \& Merchán-Hamann, E. (2008). Homens que fazem sexo com homens: Uso dos serviços de saúde para prevenção/controle de HIV/AIDS em Brasília-DF. Comunicação em Ciências da Saúde, 19(1), 25-34.

Madureira, V. S. F., \& Trentini, M. (2008a). Relações de poder na vida conjugal e prevenção da AIDS. Revista Brasileira de Enfermagem, 61(5), 637642.

Madureira, V. S. F., \& Trentini, M. (2008b). Da utilização do preservativo masculino à prevenção de DST/aids. Ciência \& Saúde Coletiva, 13(6), 1807-1816.

Maksud, I. (2009). O discurso da prevenção da Aids frente às lógicas sexuais de casais sorodiscordantes: Sobre normas e práticas. Physis - Revista de Saúde Coletiva, 19(2), 349-369.

Maliska, I. C. A., Souza, M. I. C., \& Silva, D. M. G. V. (2007). Práticas sexuais e o uso do preservativo entre mulheres com HIV/aids. Ciência, Cuidado e Saúde, 6(4), 471-478.

Malta, M., Magnanini, M. M. F., Mello, M. B., Pascom, A. R. P., Linhares, Y., \& Bastos, F. I. (2010). HIV prevalence among female sex workers, drug users and men who have sex with men in Brazil: A systematic review and metaanalysis. BMC Public Health, 10(317).

Marta, C. B., Francisco, M. T. R., Martins, E. R. C., \& Clos, A. C. (2008). A prevenção da AIDS entre estudantes ao iniciar o curso de graduação em Enfermagem. Revista de Enfermagem, 16(4), $557-561$

Maschio, M. B. M., Balbino, A. P., Souza, P. F. R., \& Kalinke, L. P. (2011). Sexualidade na terceira idade: Medidas de prevenção para doenças sexualmente transmissíveis e AIDS. Revista Gaúcha de Enfermagem, 32(3), 583-589.
Matos, E. B., Veiga, R. T., \& Reis, Z. S. N. (2009). Intenção de uso de preservativo masculino entre jovens estudantes de Belo Horizonte: Um alerta aos ginecologistas. Revista Brasileira de Ginecologia \& Obstetrícia, 31(11), 574-580.

Ministério da Saúde. (2009, jul.). Plano Integrado de enfrentamento da feminização da Epidemia de Aids e outras DST [Versão revisada]. Brasília, DF: Autor. Recuperado em 15 maio, 2012, de http://sistemas.aids.gov.br/feminizacao/sites/default/files/PlanoIntegrado-2009.pdf

Ministério da Saúde. (2011). Boletim Epidemiológico: Aids-DST [Versão preliminar]. Brasília, DF: Autor.

Moura, A. D. A., Lima, G. G., Farias, L. M., Feitoza, A. R., \& Barroso, M. G. T. (2009). Prostituição x DST/Aids: Um estudo descritivo com perspectiva de práticas de prevenção. DST - Jornal Brasileiro de Doenças Sexualmente Transmissiveis, 21(3), 143-148.

Nicolau, A. I. O., \& Pinheiro, A. K. B. (2010). Knowledge, attitude and practice of women prisoners on male and female condoms - Preview note. Online Brazilian Journal of Nursing, 9(1).

Oliveira, N. S., Moura, E. R. F., Guedes, T. G., \& Almeida, P. C. (2008). Conhecimento e promoção do uso do preservativo feminino por profissionais de unidades de referência para DST/HIV de Fortaleza-CE: O preservativo feminino precisa sair da vitrine. Saúde e Sociedade, 17(1), 107116.

Ostrow, D. G., Silverberg, M. J., Cook, R. L., Chmiel, J. S., Johnson, L., Li, X., \& Jacobson, L. P. (2008). Prospective Study of Attitudinal and Relationship Predictors of Sexual Risk in the Multicenter AIDS Cohort Study. AIDS and Behavior, 12, 127-138.

Paiva, V. (2000). Fazendo arte com camisinha. São Paulo, SP: Summus.

Paiva, V., Calazans, G., Venturi, G., Dias, R., \& Grupo de Estudos em População, Sexualidade e Aids. (2008). Idade e uso de preservativo na iniciação sexual de adolescentes brasileiros. Revista de Saúde Pública, 42(Supl. 1), 45-53.

Paiva, V., Venturi, G., França, I., Jr., \& Lopes, F. (2003). Uso de preservativos: Pesquisa Nacional MS / IBOPE, Brasil. Recuperado em 02 junho, 2012, de http://nepaids.vitis.uspnet.usp.br/ wp-content/uploads/2010/04/artigo_preservativo.pdf 
Parker, R. G. (1994). A construção da solidariedade: AIDS, sexualidade e política no Brasil. Rio de Janeiro, RJ: Relume-Dumará.

Petchesky, R. P. (1999). Direitos sexuais: Um novo conceito na prática política internacional. In $\mathrm{R}$. M. Barbosa \& R. Parker (Orgs.), Sexualidades pelo avesso: Direitos, identidades e poder. Rio de Janeiro, RJ: Instituto de Medicina Social, Universidade Estadual do Rio de Janeiro.

Rebello, L. E. F. S., Gomes, R., \& Souza, A. C. B. (2011). Homens e a prevenção da aids: Análise da produção do conhecimento da área da saúde. Interface - Comunicação, Saúde, Educação, 15(36), 67-78.

Reis, C. B., \& Bernardes, E. B. (2011). O que acontece atrás das grades: Estratégias de prevenção desenvolvidas nas delegacias civis contra HIV/ AIDS e outras doenças sexualmente transmissíveis. Ciência \& Saúde Coletiva, 16(7), 33313338.

Reis, R. K., \& Gir, E. (2009). Vulnerabilidade ao HIV/AIDS e a prevenção da transmissão sexual entre casais sorodiscordantes. Revista da Escola de Enfermagem da USP, 43(3), 662-669.

Ribeiro, K. C. S., Silva, J., \& Saldanha, A. A. W. (2011). Querer é poder? A ausência do uso de preservativo nos relatos de mulheres jovens. DST - Jornal Brasileiro de Doenças Sexualmente Transmissiveis, 23(2), 84-89.

Riscado, J. L. S., Oliveira, M. A. B., \& Brito, Â. M. B. B. (2010). Vivenciando o racismo e a violência: Um estudo sobre as vulnerabilidades da mulher negra e a busca de prevenção do HIV/aids em comunidades remanescentes de Quilombos, em Alagoas. Saúde e Sociedade, 19(Supl. 2), 96108.

Saldanha, A. A. W., Carvalho, E. A. B., Diniz, R. F., Freitas, E. S., Félix, S. M. F., \& Silva, E. A. A. (2008). Comportamento sexual e vulnerabilidade à AIDS: Um estudo descritivo com perspectiva de práticas de prevenção. DST - Jornal Brasileiro de Doenças Sexualmente Transmissiveis, 20(1), 36-44.
Sampaio, J., Paixão, L. A., Andrade, P. M., \& Torres, T. S. (2010). Gênero, sexualidade e práticas de prevenção das DST/Aids: Produções discursivas de profissionais da saúde da família e de adolescentes do Vale do São Francisco. Psicologia: Teoria e Prática, 12(2), 173-187.

Sampaio, J., Santos, R. C., Callou, J. L. L., \& Souza, B. B. C. (2011). Ele não quer com camisinha e eu quero me prevenir: Exposição de adolescentes do sexo feminino às DST/aids no semi-árido nordestino. Saúde e Sociedade, 20(1), 171-181.

Sousa, A. A., Lucareski, M. A., Brizolara, R. V., Bortoletto, C. C. P., \& Pinto, W. (2009). Pavio Erótico: Uma experiência de Suzano na prevenção das DST/HIV/Aids e fomento da arte erótica. Saúde e Sociedade, 18(Supl. 1), 63-65.

Sousa, M. C. P., Espírito Santo, A. C. G., \& Motta, S. K. A. (2008). Gênero, vulnerabilidade das mulheres ao HIV/Aids e ações de prevenção em bairro da periferia de Teresina, Piauí, Brasil. Saúde e Sociedade, 17(2), 58-68.

Tesser, C. D. (2006). Medicalização social (I): O excessivo sucesso do epistemicídio moderno na saúde. Interface - Comunicação, Saúde, Educação, 10(19), 61-76.

United Nations Organization. (2011). The Secretary-General Message on World Aids Day (1 December 2011). Retrieved May 10, 2012, from http://www.unaids.org/en/media/unaids/contentassets/documents/speech/2011/20111128_ UNSG_message_WAD2011_en.pdf

Viana, F. J. M., Faúndes, A., Mello, M. B., \& Sousa, M. H. (2007). Factors associated with safe sex among public school students in Minas Gerais, Brazil. Cadernos de Saúde Pública, 23(1), 43-51.

Recebido: $30 / 08 / 2012$

$1^{a}$ revisão: 07/09/2012

Aceite final: 13/09/2012 